\begin{tabular}{cc}
\hline & \\
4 &
\end{tabular}

\title{
A patient with dysphagia and muscle weakness
}

\section{J. Kelly Smith MD, FACP ${ }^{1^{*}}$, Blair Reece, MD $^{2}$, Clint Smith, BS ${ }^{1}$}

${ }^{1}$ Departments of Academic Affairs and Biomedical Sciences, James H. Quillen College of Medicine, East Tennessee State University, Johnson City, Tennessee; ${ }^{2}$ Division of General Internal Medicine, Department of Internal Medicine, James H. Quillen College of Medicine, East Tennessee State University,Johnson City, Tennessee

\section{BACKGROUND:}

There are five major types of inflammatory myopathies (IM), including dermatomyositis, polymyositis, immune-mediated necrotizing myopathy, antisynthetase syndromes, and inclusion body myositis. Grouped together, the incidence of IM is $>4$ cases/100,000 with a prevalence of 14-32/100,000. Type-specific IM diagnoses are based on the pattern of muscle weakness and the results of electromyographs, MRIs, muscle biopsies, and measurements of myositis-specific autoantibodies ${ }^{1}$.

We report the case of an elderly man with an inflammatory myopathy whose presenting complaint was dysphagia.

\section{OBJECTIVE:}

To review the clinical and laboratory manifestations of inflammatory myopathy-associated dysphagia.

\section{CASE REPORT:}

The patient is an 81-year-old retired Navy aviator who presented with a chief complaint of difficulty in swallowing both solids and liquids of several months duration. The dysphagia was associated with bouts of coughing, the expectoration of white foamy sputum, increased production of saliva, a weight loss of $5 \mathrm{~kg}$, generalized myalgias, and worsening fatigue and weakness.

The patient had a past medical history of essential hypertension, hyperlipidemia, autoimmune thyroiditis, V617F JAK2 + essential thrombocytosis, white matter microangiopathy, and a small lacunar infarction of the right caudate nucleus. There was no family history of autoimmune disease.

\section{*Correspondence to Author:}

J. Kelly Smith MD, FACP

Departments of Academic Affairs and Biomedical Sciences, James $\mathrm{H}$. Quillen College of Medicine, East Tennessee State University, Johnson City, Tennessee

How to cite this article:

J. Kelly Smith, Blair Reece, Clint Smith. A patient with dysphagia and muscle weakness. International Journal of Case Reports, 2019 4:105.

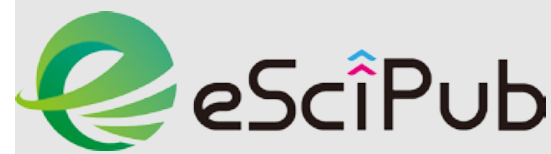

eSciPub LLC, Houston, TX USA. Website: https://escipub.com/ 
On neurological examination, testing of cranial nerves II-XII and sensation to light touch, pin, temperature, and vibration was normal. The shoulder and upper arm strength was diminished bilaterally without evident muscle tenderness, atrophy or fasciculations. The patient could not rise from the supine position without assistance nor keep his arms elevated above his head without fatiguing. The strength in his lower extremities was normal. Deep tendon reflexes were normal and plantar responses were flexor. He had a single Gottron's nodule and a faint erythematous rash involving his scalp, back and forearms. His Myositis Disease Activity Assessment (MDAAT) is shown in Table 1.

\section{Table 1. Myositis Disease Activity Assessment Tool (MDAAT)}

\begin{tabular}{|c|c|c|}
\hline $\begin{array}{l}\text { Constitutional: } \\
\text { Pyrexia }\left(>38^{\circ} \mathrm{C}\right) \text { - } 0 \\
\text { Unintentional weight loss }>5 \%-3 \\
\text { Fatigue/malaise/lethargy - } 3 \\
\text { Mucocutaneous: } \\
\text { Ulceration - } 0 \\
\text { Erythroderma - } 0 \\
\text { Panniculitis - } 0 \\
\text { Erythematous rashes - } 1 \\
\text { Heliotrope rash - } 0 \\
\text { Gottron's papules/sign }-2 \\
\text { Periungual capillary changes }-0 \\
\text { Alopecia - } 0 \\
\text { Mechanics hands - } 0 \\
\text { Skeletal: } \\
\text { Arthritis - } 0 \\
\text { Arthralgia - } 2\end{array}$ & $\begin{array}{l}\text { Pulmonary: } \\
\text { Respiratory muscle disease without } \\
\text { interstitial lung disease (ILD): } \\
\text { a. Dyspnea at rest - } 0 \\
\text { b. Dyspnea on exertion - } 3 \\
\text { c. Active reversible ILD - } 0 \\
\text { Dysphonia } \\
\text { a. Moderate to severe - } 0 \\
\text { b. Mild - } 3 \\
\text { Gastrointestinal: } \\
\text { Moderate/severe dysphagia - } 3 \\
\text { Abdominal pain - } 0 \\
\text { Cardiac: } \\
\text { Pericarditis - } 0 \\
\text { Myocarditis - } 0 \\
\text { Arrhythmia - } 0 \\
\text { Sinus tachycardia - } 0\end{array}$ & $\begin{array}{l}\text { Muscle: } \\
\text { Severe muscle inflammation - } 3 \\
\text { Myalgia - } 3 \\
\text { Global Disease Activity: } 3\end{array}$ \\
\hline
\end{tabular}

The patient's MDAAT assessment. Scoring: $0=$ not present in the past 4 weeks; 1 = clinically significant improvement in the last 4 weeks compared to the previous 4 weeks; $2=$ no change in the past 4 weeks compared to the previous 4 weeks; $3=$ clinically significant deterioration in the past 4 weeks compared to the previous 4 weeks; $4=$ new in the past 4 weeks

Findings on laboratory assessment included a normochromic normocytic anemia, thrombocythemia, a positive FANA IgG titer of 1:1280, and elevated levels of creatinine phosphokinase $(1,373 \mathrm{U} / \mathrm{L})$, aldolase $(25.8 \mathrm{U} / \mathrm{L})$, and antibodies to Mi-2 alpha, Mi-2 beta, MDA-5 and NXP-2 antigens. Anti-doubled stranded DNA, anti-RNP, anti-SM, anti-Jo-1, anti-SRP, anti-TIF-1Y and anti-synthetase antibody titers were negative. A modified barium swallow revealed severe oropharyngeal dysfunction with aspiration. An electromyograph, a muscle biopsy, and a MRI of cervical spinal muscles were indicative of an inflammatory myopathy.

\section{DISCUSSION:}

Dysphagia as a result of weakness of the oropharyngeal, laryngeal and esophageal musculature has been reported to develop in $10 \%$ to $73 \%$ of patients with inflammatory myopathy (IM) at some time during the course of their disease, and is most frequently seen in 
those with inclusion body myositis or malignancy- associated dermatomyositis.

In a Mayo Clinic review of 62 patients with IMassociated dysphagia, $42 \%$ had inclusion body myositis, $29 \%$ dermatomyositis, $15 \%$ polymyositis, and $15 \%$ an overlap syndrome. Dysphagia as the presenting complaint was most common in patients with inclusion body myositis (42\%) followed by polymyositis and the overlap syndrome (11\% each). IM-associated dysphagia had a mortality rate of $31 \%-64 \%$ with the highest incidence of death occurring in patients with percutaneous endoscopic gastrostomies, an indirect measure of the severity of dysphagia. Death was most commonly the result of recurrent aspiration ${ }^{2}$.
In a study of 92 patients with adult-onset dermatomyositis, Mugii and associates found that dysphagia was most prevalent in elderly patients, in males, and in patients with internal malignancies and/or elevated anti-TIF-1Y antibody levels ${ }^{3}$. In keeping with this report, the presented case is an elderly man with clinical and immunological evidence supporting a diagnosis of dermatomyositis, including an erythematous rash, a Gottron's sign, and antiMi-2, anti-MDA-5, and anti-NXP-2 antibodies autoantibodies associated with myositis, a classic dermatomyositis rash, and possible malignancy (see Table 2).

\section{Table 2. Patient's myositis-specific autoantibodies *}

\begin{tabular}{|l|l|l|}
\hline Antibody & Cellular target & Disease associations \\
\hline Anti-Mi-2 & $\begin{array}{l}\text { Component of the nucleosome remodeling- } \\
\text { deacetylase (NuRD) complex. Involved in } \\
\text { transcription regulation. }\end{array}$ & $\begin{array}{l}\text { Myositis (generally mild) } \\
\text { Classic DM rash }\end{array}$ \\
\hline Anti-NXP-2 & $\begin{array}{l}\text { Nuclear matrix protein 2. Plays a role in diverse } \\
\text { nuclear functions including RNA metabolism, } \\
\text { maintenance of nuclear architecture, and } \\
\text { regulation of activation of tumor suppressor gene } \\
\text { p53 }\end{array}$ & $\begin{array}{l}\text { Myositis (generally mild) } \\
\text { Classic DM rash } \\
\text { Calcinosis } \\
\text { Malignancy } \\
\text { DM (possible) }\end{array}$ \\
\hline Anti-MDA-5 & $\begin{array}{l}\text { Melanoma differentiation associated gene 5. A } \\
\text { RNA helicase encoded by MDA-5 is involved in } \\
\text { innate immune defense against viruses }\end{array}$ & $\begin{array}{l}\text { Amyotrophic or mild myositis } \\
\text { Classic DM rash } \\
\text { ILD possible } \\
\text { Palmar pustules } \\
\text { Raynaud phenomenon }\end{array}$ \\
\hline
\end{tabular}

*see reference 5. DM, dermatomyositis; ILD, interstitial lung disease.

Agents most commonly used and reported to be beneficial in treating IM-associated dysphagia include prednisone, azathioprine, methotrexate, intravenous immunoglobulin, hydroxychloroquine, and mycophenolate mofetil. Interventional procedures include enteral feeding and cricopharyngeal myotomies and dilations ${ }^{2}$. Inclusion body myositis is often recalcitrant to immunosuppressive treatment and is more likely to require interventional measures ${ }^{4}$. Our patient's dysphagia is improving on methotrexate and prednisone.

It is important to note that myositis patients presenting with complaints of dysphagia and weakness may be misdiagnosed as having amyotrophic lateral sclerosis, a disease in which serum CPK levels may be elevated and bulbar onset is common.

\section{REFERENCES:}


1. Greensberg SA, Amato AA. Inflammatory myopathies. In: Jameson JL, Fauci AS, Kasper DL, Hauser SL, Longo DL, Loscalzo J, editors. Harrison's Principles of Internal Medicine, $20^{\text {th }} \mathrm{ed}$. New York: McGraw Hill; 2018. p. 2590-2597.

2. Oh TH, Brumfield KA, Hoskin TL, Stolp KA, Murray JA, Basford JR. Dysphagia in inflammatory myopathy: clinical characteristics, treatment strategies, and outcome in 62 patients. Mayo Clin Proc. 2007; 82(4):441-7.

3. Mugii N, Hasegawa M, Matsushita T, Hamaguchi $Y$, Oohata S, Okita $H$, et. al. Oropharyngeal dysphagia in dermatomyositis: associations with clinical and laboratory features including autoantibodies. PLoS One. 2016; 11(5):e0154746.

doi:10.1371/journal.pone.0154746

4. Darrow DH, Hoffman HT, Barnes GJ, Wiley CA. Management of dysphagia in inclusion body myositis. Arch Otolaryngol Head Neck Surg. 1992; 118(3):313-317.

5. Damoiseaux J, Vulsteke J-B, Tseng C-W, Platteel ACM, Piette Y, Shovman O, et. al. Autoantibodies in idiopathic inflammatory myopathies: clinical associations and laboratory evaluation by monoand multispecific immunoassays. Autoimm Rev. 2019; 18:293-305

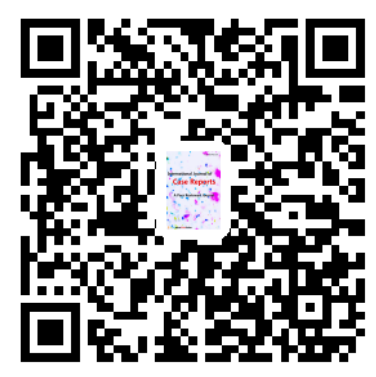

